\title{
The allocation of leprosy patients into paucibacillary and multibacillary groups for multidrug therapy, taking into account the number of body areas affected by skin, or skin and nerve lesions
}

\author{
W $\mathrm{H}$ VAN BRAKEL, $* \S \mathrm{R}$ DE SOLDENHOFF $\dagger \&$ \\ A C MCDOUGALL $\ddagger$ \\ *International Nepal Fellowship Leprosy Control Project, c/o INF, \\ PO Box 5, Pokhara, Nepal; †Eastern Leprosy Control Project, c/o \\ NSL, PO Box 134, Biratnagar, Nepal; $₫ 87$ Lower Radley, Near \\ Abingdon, Oxford OX14 3BA, England
}

Accepted for publication 14 February 1992

\begin{abstract}
Summary In Nepal, the setting up and maintaining of reliable services for slitskin smears has proven difficult. A clinical classification system for leprosy has therefore been developed to assist in the allocation of patients to either paucibacillary or multibacillary groups for the purposes of multiple drug therapy (MDT), using 9 body areas: head (1), arms (2), legs (2), trunk (4). Patients with more than two areas of the body affected are grouped as multibacillary (MB) and those with only one or two areas affected are paucibacillary (PB). Using a computer simulation model and the data of 53 patients registered at Green Pastures Hospital (GPH) in Pokhara and 703 field patients from the Western Region, different clinical classification systems were evaluated with regard to their sensitivity, specificity, and predictive value for MB or PB classification, as compared with the histological classification for the GPH cases and the bacteriological classification for the field patients. The sensitivity and specificity of the body area system in present use were $93 \%$ and $39 \%$, respectively. The low specificity is due to MB overclassification. The sensitivity of the WHO classification system without skin smear facilities is $73 \%$ (the difference with the body area system is significant: $p<0 \cdot 05$, McNemar's test). Our histology findings confirm previous publications indicating that, while some borderline-tuberculoid (BT) patients may outwardly have a 'PB appearance' and be skin-smear negative, their nerve biopsy and sometimes skin biopsy may show a ' $\mathrm{MB}$ ' picture. This is the first publication discussing a 'body area system' for the purpose described, including diagrams of the areas used. In Nepal it has proved easy to use and teach and its use may be justified in other control programmes which implement MDT, particularly if slit-skin smear services are unreliable or nonexistant.
\end{abstract}




\section{Introduction}

Leprosy control in Nepal has peculiar difficulties-mountainous terrain, long distances between treatment centres and patients, poorly developed communications and limited financial resources. It was noticed several years ago that in Nepal a considerable proportion of ostensibly borderline-tuberculoid patients have a 'BT' appearance, are skin-smear negative, but have widespread skin and nerve lesions and therefore give a 'multibacillary impression' (see case reports below). Partly because of these considerations, but also because of the difficulty of establishing and maintaining reliable slit-skin smear services, the International Nepal Fellowship (INF)/German Leprosy Relief Association (DAHW) supported Leprosy Control Project (LCP) in the Western and MidWestern Regions of Nepal and the Netherlands Leprosy Relief Association (NSL) supported Eastern Leprosy Control Project (ELCP) accepted the policy in $1986^{1}$ of allocating patients to either paucibacillary (PB) or multibacillary (MB) World Health Organization (WHO) treatment regimens, ${ }^{2}$ taking account of the number of body areas involved by skin lesions, skin and nerve lesions, or any type of secondary damage attributable to leprosy. A number of recent publications have stressed the need for a simple and reliable classification system that is based on clinical parameters, ${ }^{3-7}$ as opposed to a system which depends on the availability of a reliable skin-smear service.

This paper describes experience with the use of this system during the past 5 years in two different centres in Nepal and discusses its possible value in relation to other systems which have the same objective, but which are based on counts of the number of skin, or skin and nerve lesions. The effects on different parameters of increasing or decreasing the number of body areas as a cut-off point for $\mathrm{MB}$ classification are also discussed.

\section{Methods}

\section{CASE SELECTION}

Case-finding in both projects is based on voluntary presentation, encouraged by multimedia health education. The average disability proportion (at least WHO grade 2$)^{8}$ among new cases in the Western Region is $22 \%,{ }^{9}$ so there is still a considerable casefinding delay with many patients. The diagnosis 'leprosy' is based on finding either acidfast bacilli in the slit-skin smear, a definitely enlarged peripheral nerve trunk or a definitely anaesthetic skin lesion. Despite the operational difficulties, $98 \%$ of newly registered cases have skin smears taken, ${ }^{9}$ but the result in the field may be delayed for $2-3$ months. The quality of the smear taking often leaves much to be desired, despite frequent refresher courses.

Out of 377 patients registering as new cases at Green Pastures Hospital (GPH) in Pokhara between January 1987 and June 1991, 53 consecutive cases were enrolled in the study. Similarly, 703 consecutive cases, newly registered between January 1990 and June 1991 at the Western Regional mobile clinic, were included for analysis. The cases were random in that all GPH patients registered after September 1990 were included whose histology results were already available by August 1991. For the field cases all new registrations with skin-smear results were included. Cases for whom the body area score was not available were excluded from the analysis. 


\section{CLASSIFICATION}

In 1985, the INF published a Manual for the Implementation of Multidrug Therapy in the Leprosy Control Programme of Nepal. ${ }^{1}$ It included the proposal that the allocation of patients to PB or MB groups, for the purpose of MDT, could be based on a count of the number of body areas involved by skin, or skin and nerve lesions. Between the different agencies operating in leprosy control in Nepal there has been some variation in the application of this system in practice, notably with regard to the precise demarcation of the body areas. The INF LCP in the West have used a total of 9, while in the East the ELCP used a total of 7. The diagrams in Figure 1 represent a consensus view of what has been used, for the head, arms, legs and trunk. In the ELCP the trunk is only divided into back and front, there being 2 areas less. It was advised that any patient with skin, or skin and nerve lesions on more than two areas of the body should be grouped as MB for the purpose of MDT. Thus any patients with only one or two areas involved would be grouped as PB. The precise definition of 'nerve lesions' or 'nerve involvement' has proved
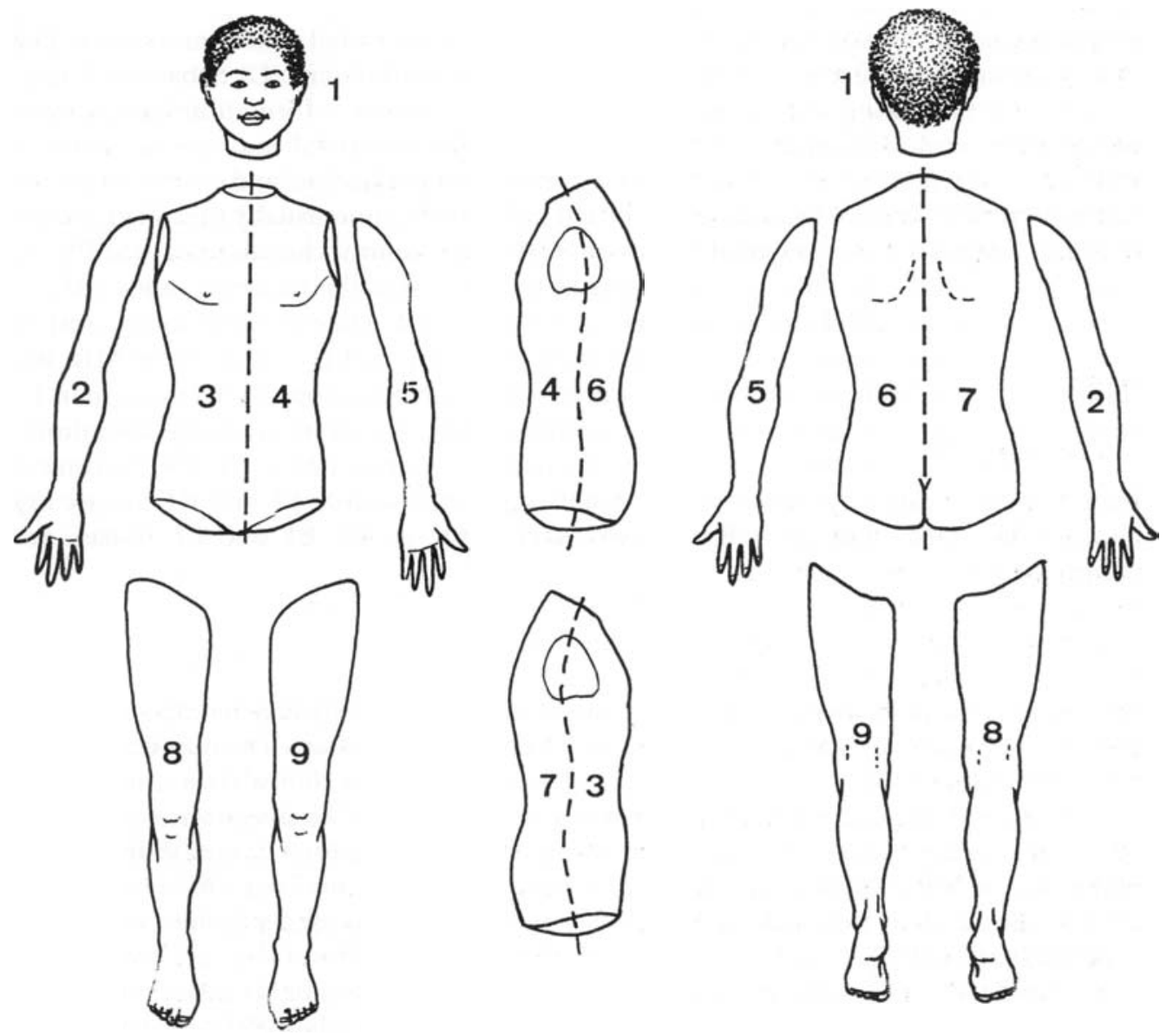

Figure 1. 
somewhat difficult, but our policy has been to accept sensory and/or motor defects due to lesions of the facial, ulnar, radial, median, lateral popliteal, posterior tibial, sural and superficial peroneal nerves as being due to leprosy, especially if associated with typical skin lesions. Patients with nerve defects only are routinely referred to a supervisor and if necessary to a medical officer. The staff are trained in the recognition of deformity due to conditions other than leprosy, such as poliomyelitis, birth injury and trauma. In practice the term 'nerve involvement' has included claw hand, drop foot, lagophthalmos, absorption of the extremities, and ulceration of the hand or foot.

In addition to this system, the Ridley-Jopling classification ${ }^{10}$ was also used, looking at clinical appearance and skin-smear results for the final classification. The clinical appearance was assessed using a classification chart as described by Jopling. ${ }^{11}$ Correlation of the clinical and histological classification was found to be good $(r=0 \cdot 72$, see Table 7). All newly registered cases had skin smears taken from 3 routine sites (earlobe, elbow and knee) and from one or two of the most active looking skin lesions. All the skin smears of the cases described below were processed and read at the same reference laboratory at GPH in Pokhara. Since September 1990 all newly registered cases at GPH have also had a skin biopsy taken from an active looking skin lesion and/or a nerve biopsy taken from, when possible, an enlarged sensory nerve (usually one of the radial cutaneous nerves). The biopsy specimens were fixed in FMA and sent to a histopathologist (Dr Sebastian Lucas, London) for processing and reading. Along with the specimen, information was also sent on the clinical classification, appearance of the lesions biopsied and the presence or absence of any leprosy reactions. When the clinical classification and a skin smear or histology result were not in agreement, the clinical classification usually prevailed, unless the $\mathrm{BI}$ or histology result revealed MB disease while the clinical classification was PB. In that case the final classification was changed to agree with the bacterial index (BI) or histology result. At GPH any positive $\mathrm{BI}$ is considered $\mathrm{MB}$, while in the histology a $\mathrm{BI}$ of more than 1 and/or a histological classification of $\mathrm{BB}, \mathrm{BL}$ or LL is taken to be $\mathrm{MB}$. We realize that the definitions of ' $\mathrm{MB}$ ', particularly the histological one of 'BI more than 1', need further scientific validation, but we accepted them as current working definitions.

The WHO classification referred to in this paper is as described in the 1988 Technical Report Series, ${ }^{8}$ namely that skin-smear negative patients with I, TT and BT disease are paucibacillary and patients with a positive skin smear or BB, BL and LL disease are multibacillary.

\section{COMPUTER SIMULATION}

An analysis was done using the data of a sub-set of 53 cases newly registered at GPH and 703 patients newly registered in the Western Regional mobile clinic. The number of body areas involved in the disease was recorded and, along with other clinical data, entered into a computer database, using Epi Info software, version 5.01. ${ }^{12}$ Classification according to the number of body areas involved in the disease was then simulated, taking different cutoff points for $\mathrm{MB}$ classification $(\mathrm{BC} 2=2$ or more body areas involved, $\mathrm{BC} 3=3$ or more areas involved, etc.). Also a clinical classification system (CCS) used in India ${ }^{13}$ (where the paucibacillary regimen is advised for indeterminate, tuberculoid (TT) and borderlinetuberculoid (BT) cases with less than 10 skin/nerve trunk lesions only) was simulated, as well as the current WHO classification recommendations, using the GPH case data. In the model used, the effects of the absence or availability of skin-smear results could also be 
studied among the GPH cases. The MB or PB classifications obtained using the different C.CSs were then compared with the histology classification for the GPH cases and the bacteriological classification for the field cases. The latter is based on the current WHO recommendation that all skin-smear positive patients should be treated with MB MDT. ${ }^{8}$ Thus the sensitivity, specificity and predictive values for MB and PB classification could be calculated for each of the different classification systems.

\section{STATISTICS}

The significance of the difference between the various proportions was tested with McNemar's paired Chi-squared test (Armitage, p. 121). ${ }^{14}$ The difference between 2 unpaired sample means was tested using the standardized normal deviate (SND or z-test, Armitage, p. 106). ${ }^{14} \mathrm{~A} p$-value of less than 5\% was used as the level of statistical significance. The correlation coefficient used (Table 8) is as in Armitage, p. $150 \mathrm{ff} .{ }^{14}$ Of the most important proportions the $95 \%$ confidence interval is given in brackets behind the proportion, e.g. $14 \%( \pm 12 \%)$ means that there is $95 \%$ chance that the proportion actually lies between the values $2 \%$ and $26 \%$.

\section{Case reports}

CASE NO. 20 (see Table 10)

A 33-year-old male patient had had symptoms of paraesthesia and anaesthesia for 2 years. He had not yet received any treatment. On examination, many $(>20)$ hypopigmented dry macules of varying sizes were found, mainly on his limbs and face. Some were anaesthetic, but not all. Some were well defined and others were not. Both ulnar and lateral popliteal nerves, the left radial cutaneous and posterior tibial nerve and the right greater auricular nerve were enlarged and he already had anaesthetic areas on his hands and feet. His voluntary muscle test (VMT) showed ulnar nerve function loss. There were a total of 9 body areas involved and his disability grade was 2 . Skin smears from 4 sites were negative for acid-fast bacilli (AFB). He was classified as MB-BT and put on MB MDT. The biopsies revealed the skin and nerve specimens to be borderline with a skin BI of 3 and a nerve $\mathrm{BI}$ of 4 .

\section{CASE NO. 28}

A 32-year-old male patient came to GPH with symptoms of 3 years duration. He was concerned about the increasing number of patches on his skin. Examination showed many ( $>20$ ) hypopigmented, mainly large and well-defined, nonanaesthetic macules all over his body. The left ulnar, radial cutaneous, lateral popliteal and superficial peroneal nerves were enlarged. He showed nerve function loss of both ulnar nerves. Nine body areas were involved and his disability grade was 1 . The skin smear for AFB was negative at 4 sites but his classification was MB-BT and the patient was started on MB MDT. The result of the skin biopsy was BT with a BI of 2 and the biopsy of the nerve was florid tuberculoid leprosy, but with a BI of 4 . 
CASE NO. 33

A 31-year-old male patient gave a history of having had symptoms for only 1 month, starting with parasthesia in his right hand. On examination there were fifteen, mostly illdefined, anaesthetic, hypopigmented macules of different sizes, mainly on the arms, legs and buttocks. Both ulnar, radial cutaneous, lateral popliteal and superficial peroneal nerves were enlarged, as well as the right posterior tibial nerve. There was also nerve function loss of both ulnar nerves and the left lateral popliteal nerve. There were 6 body areas involved and the disability grade was 1 . Skin smears for AFB were negative at 4 sites. Our classification according to the body area system was MB-BT and therefore MB MDT was started. The biopsy result of the nerve indicated BT leprosy with a $\mathrm{BI}=3 \cdot 5$, while the skin biopsy showed BT disease with no AFB.

\section{CASE NO. 38}

A 36-year-old male patient presented mainly for the treatment of a complicated ulcer on his right foot. Although he had already had the disease for 10 years he had not previously received treatment. The clinical examination showed many $(>20)$ hypopigmented, mostly anaesthetic and well-defined macules with a dry and rough surface of differing sizes. Both ulnar, supra orbital and greater auricular nerves were enlarged. His hands and feet were anaesthetic with some shortening of fingers and toes. There were 9 body areas involved and his disability grade was 2 . Skin smears for AFB were negative at 5 sites. The classification, according to the body area system, was MB-BT and treatment with MB MDT was started. The biopsy result of the skin indicated BT leprosy with a BI of 2 . The nerve biopsy showed mainly fibrous tissue with few nerve fibres. There were no AFB and no specific label was able to be given.

\section{Results}

Tables 1 and 2 describe the age and sex distribution of the study cases. Although in all 3 groups the age peak falls in the 30-44 age group, the average age of the field patients is younger than the GPH patients. The male: female ratio is higher in GPH than in the field

Table 1. Age distribution of the study cases

\begin{tabular}{|c|c|c|c|c|c|c|}
\hline \multirow{2}{*}{$\begin{array}{l}\text { Age } \\
\text { group }\end{array}$} & \multicolumn{2}{|c|}{ GP all } & \multicolumn{2}{|c|}{ GP histology } & \multicolumn{2}{|c|}{ Field } \\
\hline & Freq. & $\%$ & Freq. & $\%$ & Freq. & $\%$ \\
\hline $0-14$ & 14 & $3 \cdot 7$ & 2 & $3 \cdot 8$ & 45 & $6 \cdot 4$ \\
\hline $15-29$ & 72 & $19 \cdot 1$ & 6 & $11 \cdot 3$ & 162 & $23 \cdot 0$ \\
\hline $30-44$ & 138 & $36 \cdot 6$ & 24 & $45 \cdot 3$ & 225 & $32 \cdot 0$ \\
\hline $45-59$ & 92 & $24 \cdot 4$ & 14 & $26 \cdot 4$ & 186 & $26 \cdot 5$ \\
\hline $60-74$ & 54 & $14 \cdot 3$ & 7 & $13 \cdot 2$ & 74 & $10 \cdot 5$ \\
\hline $75-95$ & 7 & 1.9 & 0 & & 11 & $1 \cdot 5$ \\
\hline Total & 377 & $100 \cdot 0$ & 53 & $100 \cdot 0$ & 703 & $100 \cdot 0$ \\
\hline
\end{tabular}

Table 2. Sex distribution of study cases

\begin{tabular}{|c|c|c|c|c|c|c|}
\hline \multirow[b]{2}{*}{ Sex } & \multicolumn{2}{|c|}{ GP all } & \multicolumn{2}{|c|}{ GP histology } & \multicolumn{2}{|c|}{ Field } \\
\hline & Freq. & $\%$ & Freq. & $\%$ & Freq. & $\%$ \\
\hline $\mathrm{F}$ & 111 & $29 \cdot 4$ & 19 & $35 \cdot 8$ & 259 & $36 \cdot 8$ \\
\hline M & 266 & $70 \cdot 6$ & 34 & $64 \cdot 2$ & 444 & $63 \cdot 2$ \\
\hline Total & 377 & $100 \cdot 0$ & 53 & $100 \cdot 0$ & 703 & $100 \cdot 0$ \\
\hline
\end{tabular}


( 2.4 and 1.7 respectively), stressing the fact that field-based health services are more easily accessible for women, than referral centres. Table 3 shows the differential classification of the study cases, according to the Ridley-Jopling classification. No indeterminate cases were registered, but there is a striking difference between the proportion of tuberculoid (TT) cases found in the field $(16 \cdot 5 \%)$ and in GPH $(0 \cdot 8 \%)$. The lepromatous proportion (borderline-lepromatous and lepromatous or BL-LL) is $27 \cdot 7 \%$ against $43 \cdot 4 \%$ respectively. This emphasizes the general observation that referral centres tend to see a higher proportion of more advanced cases. Table 4 shows the distribution of body areas involved in each of the study groups. There is significant difference $(p<0.001$, SND test for difference between sample means) ${ }^{14}$ between the average number of body areas involved in field patients and in GPH patients. This again supports the finding that less advanced cases more readily register for treatment in field clinics.

Tables 1-4 show that the 'histology sub-group' of the GPH cases, although small in number $(n=53)$, is a representative sample of the whole group of GPH cases. Table 5 shows a breakdown of the cases in this sub-group, comparing MB-PB classification according to the different computer simulated clinical classifications with the MB-PB classification found histologically. The results for BT group are shown separately, since this is a significant sub-group (see Table 3), which originally led to the development and implementation of the body area system. Table 6 shows the same among field cases with the outcome of skin smears, where cases with $\mathrm{BI}=0$ are $\mathrm{PB}$ and all others are $\mathrm{MB}$. The results of the calculations of sensitivity, specificity and predictive values of MB-PB are shown in Table 7. Table 8 shows the correlation of the classification of the GPH cases, with the histological classification of the same cases. The correlation of bacteriological index with the clinical (Ridley-Jopling) classification among the field cases is shown in Table 9. Details of the 'BT sub-group' of the GPH cases are given in Table 10.

Figure 1 shows the demarcation of the body areas as used in GPH. Figure 2 shows the cumulative percentage of sensitivity and predictive value of a PB classification for GPH cases. Figure 3 shows the same for the field cases. The specificities of the different CCSs for GPH and field cases are shown in Figure 4.

Table 3. Classification of study cases according to the Ridley-Jopling system

\begin{tabular}{|c|c|c|c|c|c|c|}
\hline \multirow[b]{2}{*}{ Class } & \multicolumn{2}{|c|}{ GP all } & \multicolumn{2}{|c|}{ GP histology } & \multicolumn{2}{|c|}{ Field } \\
\hline & Freq. & $\%$ & Freq. & $\%$ & Freq. & $\%$ \\
\hline $\mathrm{TT}$ & 3 & $0 \cdot 8$ & & & 116 & $16 \cdot 5$ \\
\hline BT & 192 & $51 \cdot 1$ & 26 & $50 \cdot 0$ & 305 & $43 \cdot 4$ \\
\hline $\mathrm{BB}$ & 8 & $2 \cdot 1$ & 1 & 1.9 & 26 & $3 \cdot 7$ \\
\hline $\mathrm{BL}$ & 124 & $33 \cdot 0$ & 19 & $36 \cdot 5$ & 112 & $15 \cdot 9$ \\
\hline $\mathrm{L} L$ & 39 & $10 \cdot 4$ & 3 & $5 \cdot 8$ & 83 & $11 \cdot 8$ \\
\hline NL & 9 & $2 \cdot 4$ & 3 & $5 \cdot 8$ & 61 & $8 \cdot 7$ \\
\hline $\mathrm{NC}$ & 1 & $0 \cdot 3$ & & & & \\
\hline Total & 376 & $100 \cdot 0$ & 53 & $100 \cdot 0$ & 703 & $100 \cdot 0$ \\
\hline
\end{tabular}

NC, not classified.
Table 4. Distribution of body area involvement in the study cases

\begin{tabular}{|c|c|c|c|c|c|c|}
\hline \multirow{2}{*}{$\begin{array}{l}\text { Body } \\
\text { areas }\end{array}$} & \multicolumn{2}{|c|}{ GP all } & \multicolumn{2}{|c|}{ GP histology } & \multicolumn{2}{|c|}{ Field } \\
\hline & Freq. & $\%$ & Freq. & $\%$ & Freq. & $\%$ \\
\hline 1 & 44 & $11 \cdot 7$ & 6 & $11 \cdot 3$ & 139 & $19 \cdot 8$ \\
\hline 2 & 35 & $9 \cdot 3$ & 5 & $9 \cdot 4$ & 72 & $10 \cdot 2$ \\
\hline 3 & 27 & $7 \cdot 2$ & 7 & $13 \cdot 2$ & 91 & $12 \cdot 9$ \\
\hline 4 & 24 & $6 \cdot 4$ & 1 & 1.9 & 95 & $13 \cdot 5$ \\
\hline 5 & 25 & $6 \cdot 6$ & 5 & $9 \cdot 4$ & 97 & $13 \cdot 8$ \\
\hline 6 & 18 & $4 \cdot 8$ & 1 & 1.9 & 66 & $9 \cdot 4$ \\
\hline 7 & 37 & $9 \cdot 8$ & 2 & $3 \cdot 8$ & 47 & $6 \cdot 7$ \\
\hline 8 & 15 & $4 \cdot 0$ & 3 & $5 \cdot 7$ & 29 & $4 \cdot 1$ \\
\hline 9 & 151 & $40 \cdot 2$ & 23 & $43 \cdot 4$ & 67 & $9 \cdot 5$ \\
\hline Total & 376 & $100 \cdot 0$ & 53 & $100 \cdot 0$ & 703 & $100 \cdot 0$ \\
\hline Mean & $6 \cdot 02$ & & 5.98 & & $4 \cdot 24$ & \\
\hline $\mathrm{SD}=$ & 3.05 & & $3 \cdot 17$ & & $2 \cdot 54$ & \\
\hline
\end{tabular}


Table 5. Comparison of histological classification with different clinical classification systems in 53 patients registered as new cases at Green Pastures Hospital since August 1990

\begin{tabular}{|c|c|c|c|c|c|c|}
\hline \multirow{3}{*}{$\begin{array}{l}\text { Clinical } \\
\text { classification }\end{array}$} & \multicolumn{6}{|c|}{ Histological classification } \\
\hline & \multicolumn{3}{|c|}{ All } & \multicolumn{3}{|c|}{ BT } \\
\hline & MB & PB & Total & MB & PB & Total \\
\hline \multicolumn{7}{|l|}{ bc2 } \\
\hline MB & 30 & 17 & 47 & 7 & 15 & 22 \\
\hline $\mathrm{PB}$ & 0 & 6 & 6 & 0 & 5 & 5 \\
\hline \multicolumn{7}{|l|}{ bc3 } \\
\hline MB & 28 & 14 & 42 & 7 & 13 & 20 \\
\hline $\mathrm{PB}$ & 2 & 9 & 11 & 0 & 7 & 7 \\
\hline \multicolumn{7}{|l|}{ bc4 } \\
\hline MB & 27 & 8 & 35 & 6 & 7 & 13 \\
\hline PB & 3 & 15 & 18 & 1 & 13 & 14 \\
\hline \multicolumn{7}{|l|}{ bc5 } \\
\hline MB & 27 & 7 & 34 & 6 & 6 & 12 \\
\hline $\mathrm{PB}$ & 3 & 16 & 19 & 1 & 14 & 15 \\
\hline \multicolumn{7}{|l|}{ whol } \\
\hline MB & 22 & 1 & 23 & 0 & 0 & 0 \\
\hline PB & 8 & 22 & 30 & 7 & 20 & 27 \\
\hline \multicolumn{7}{|l|}{ who } \\
\hline MB & 24 & 4 & 28 & 1 & 3 & 4 \\
\hline $\mathrm{PB}$ & 6 & 19 & 25 & 6 & 17 & 23 \\
\hline \multicolumn{7}{|l|}{ India } \\
\hline MB & 25 & 5 & 30 & 6 & 4 & 10 \\
\hline PB & 5 & 18 & 23 & 1 & 16 & 17 \\
\hline \multicolumn{7}{|l|}{ gp } \\
\hline MB & 30 & 16 & 46 & 7 & 15 & 22 \\
\hline PB & 0 & 7 & 7 & 0 & 5 & 5 \\
\hline
\end{tabular}

bc2, cases with 2 or more body areas involved are classified as 'MB'; bc3, cases with 3 or more body areas involved are classified as 'M B'; bc4, cases with 4 or more body areas involved are classified as 'MB'; bc5, cases with 5 or more body areas involved are classified as 'MB'; whol, WHO-recommended classification criteria, ${ }^{8}$ without skin-smear services; who, same, but with skin-smear services; India, Indian CCS: $>10$ lesions $($ skin + nerve $)=\mathrm{MB}$; gp, classification system used in GPH: BC3 + skin-smear services.
Table 6. Comparison of the bacteriological classification with different clinical classification systems in 703 patients registered as new cases since January 1990 in the Western Regional Field Programme (for all cases and BT cases separately)

\begin{tabular}{|c|c|c|c|c|c|c|}
\hline \multirow{3}{*}{$\begin{array}{l}\text { Clinical } \\
\text { classification }\end{array}$} & \multicolumn{6}{|c|}{ Bacteriological classification } \\
\hline & \multicolumn{3}{|c|}{ All } & \multicolumn{3}{|c|}{ BT } \\
\hline & MB & PB & Total & MB & PB & Total \\
\hline \multicolumn{7}{|l|}{$\mathrm{bc} 2$} \\
\hline MB & 178 & 386 & 564 & 25 & 254 & 279 \\
\hline PB & 8 & 131 & 139 & 1 & 25 & 26 \\
\hline \multicolumn{7}{|l|}{ bc3 } \\
\hline MB & 173 & 319 & 492 & 24 & 232 & 256 \\
\hline PB & 13 & 198 & 211 & 2 & 47 & 49 \\
\hline \multicolumn{7}{|l|}{ bc4 } \\
\hline MB & 164 & 237 & 401 & 23 & 165 & 188 \\
\hline PB & 22 & 280 & 302 & 3 & 114 & 117 \\
\hline \multicolumn{7}{|l|}{ bc5 } \\
\hline MB & 146 & 160 & 306 & 18 & 106 & 124 \\
\hline PB & 40 & 357 & 397 & 8 & 173 & 181 \\
\hline \multicolumn{7}{|l|}{ whol } \\
\hline MB & 150 & 71 & 221 & 0 & 0 & 0 \\
\hline PB & 36 & 446 & 482 & 26 & 279 & 305 \\
\hline
\end{tabular}

bc2-whol: see Table 5.

\section{Discussion}

The method described above was used in the assessment of patients in Pokhara with regard to relapses after MDT for leprosy. ${ }^{15}$ All 22 relapse cases had more than 2 body areas involved in the disease on initial examination. The fact that many skin-smear negative patients showed clinically extensive disease, especially among BT patients, was also recognized by the WHO Expert Committee in $1988 .{ }^{8}$ In GPH, $68 \%$ of BT cases show signs of leprosy in more than 2 body areas. These findings, along with the difficulties in 
Table 7. Comparison of clinical classification systems with the histological classification for GPH cases and with bacteriological classification for the field cases

\begin{tabular}{|c|c|c|c|c|c|c|c|c|}
\hline & $\begin{array}{l}\mathrm{bc} 2 \\
(\%)\end{array}$ & $\begin{array}{l}\text { bc3 } \\
(\%)\end{array}$ & $\begin{array}{l}\text { bc4 } \\
(\%)\end{array}$ & $\begin{array}{l}\text { bc5 } \\
(\%)\end{array}$ & $\begin{array}{c}\text { whol } \\
(\%)\end{array}$ & $\begin{array}{l}\text { who } \\
(\%)\end{array}$ & $\begin{array}{c}\text { india } \\
(\%)\end{array}$ & $\underset{(\%)}{g p}$ \\
\hline \multicolumn{9}{|c|}{ Sensitivity } \\
\hline GPH & 100 & 93 & 90 & 90 & 73 & 80 & 83 & 100 \\
\hline BT & 100 & 100 & 86 & 86 & 0 & 14 & 86 & 100 \\
\hline Field & 96 & 93 & 88 & 78 & 81 & & & \\
\hline \multicolumn{9}{|c|}{ Specificity } \\
\hline GPH & 26 & 39 & 65 & 70 & 96 & 83 & 78 & 30 \\
\hline BT & 25 & 35 & 65 & 70 & 100 & 85 & 80 & 25 \\
\hline Field & 25 & 38 & 54 & 69 & 86 & & & \\
\hline \multicolumn{9}{|c|}{ False negative ratio } \\
\hline GPH & 0 & 7 & 10 & 10 & 27 & 20 & 17 & 0 \\
\hline BT & 0 & 0 & 14 & 14 & 100 & 85 & 14 & 0 \\
\hline Field & 4 & 7 & 12 & 22 & 19 & & & \\
\hline \multicolumn{9}{|c|}{ False positive ratio } \\
\hline GPH & 74 & 61 & 35 & 30 & 4 & 17 & 22 & 70 \\
\hline BT & 75 & 65 & 35 & 30 & 0 & 15 & 20 & 75 \\
\hline Field & 75 & 62 & 46 & 31 & 14 & & & \\
\hline \multicolumn{9}{|c|}{ Predictive value MB } \\
\hline GPH & 64 & 67 & 77 & 79 & 96 & 86 & 83 & 65 \\
\hline BT & 32 & 32 & 46 & 50 & & 25 & 60 & 32 \\
\hline Field & 32 & 35 & 41 & 48 & 68 & & & \\
\hline \multicolumn{9}{|c|}{ Predictive value $\mathrm{PB}$} \\
\hline GPH & 100 & 82 & 83 & 84 & 73 & 76 & 78 & 100 \\
\hline BT & 100 & 100 & 93 & 93 & 74 & 74 & 94 & 100 \\
\hline Field & 94 & 94 & 93 & 90 & 93 & & & \\
\hline
\end{tabular}

bc2-gp, see Table 5. GPH, new cases from Green Pastures Hospital, for whom histology results were available $(n=53)$. BT, BT sub-group of GPH cases $(n=27)$. Field, new cases from the Western Regional Field $(n=703)$.

Table 8. Cross tabulation of clinical classification and histological classification in 53 new cases in Green Pastures Hospital

\begin{tabular}{lrrrrrrrr}
\hline & \multicolumn{7}{c}{ Histological classification } \\
\cline { 2 - 7 } $\begin{array}{l}\text { Clinical } \\
\text { classification }\end{array}$ & NO & I & TT & BT & BB & BL & LL & Total \\
\hline NL & 1 & 0 & 1 & 1 & 0 & 0 & 0 & 3 \\
BT & 4 & 1 & 3 & 17 & 1 & 1 & 0 & 27 \\
BB & 0 & 0 & 0 & 0 & 0 & 1 & 0 & 1 \\
BL & 0 & 0 & 0 & 3 & 1 & 10 & 5 & 19 \\
LL & 0 & 0 & 0 & 0 & 0 & 0 & 3 & 3 \\
\hline Total & 5 & 1 & 4 & 21 & 2 & 12 & 8 & 53 \\
\hline
\end{tabular}

Correlation coefficient $(r)=0 \cdot 72, p<0 \cdot 001 ;(95 \%$ conf. limits: $0.56<r<0.83$ ).

NO, No signs of leprosy in the skin and/or nerve biopsy.

NL, neural leprosy (no skin lesions).
Table 9. Cross tabulation of clinical classification with bacteriological index (highest value) for field cases

\begin{tabular}{lrrrrrrr}
\hline & \multicolumn{7}{c}{ Clinical classification } \\
\cline { 2 - 6 } BI & NL & TT & BT & BB & BL & LL & Total \\
\hline 0 & 54 & 113 & 279 & 19 & 36 & 16 & 517 \\
1 & 3 & 3 & 10 & 4 & 3 & 1 & 24 \\
2 & 3 & 0 & 2 & 2 & 9 & 2 & 18 \\
3 & 1 & 0 & 6 & 0 & 18 & 7 & 32 \\
4 & 0 & 0 & 4 & 1 & 28 & 18 & 51 \\
5 & 0 & 0 & 4 & 0 & 17 & 27 & 48 \\
6 & 0 & 0 & 0 & 0 & 1 & 12 & 13 \\
\hline Total & 61 & 116 & 305 & 26 & 112 & 83 & 703 \\
\hline
\end{tabular}

NL, neural leprosy. 
Table 10. Details of the BT cases in the GPH histology group

\begin{tabular}{|c|c|c|c|c|c|c|c|c|c|c|c|c|}
\hline $\begin{array}{l}\mathrm{Pt} \\
\text { No. }\end{array}$ & Age & Sex & Class & BI & $\begin{array}{l}\text { Body } \\
\text { areas }\end{array}$ & $\begin{array}{l}\text { Skin } \\
\text { hist. } \\
\text { class. }\end{array}$ & $\begin{array}{c}\text { Skin } \\
\text { BI }\end{array}$ & $\begin{array}{l}\text { Nerve } \\
\text { hist. } \\
\text { class. }\end{array}$ & $\begin{array}{c}\text { Nerve } \\
\text { BI }\end{array}$ & $\begin{array}{l}\text { Hist. } \\
\text { MB/PB } \\
\text { Class }\end{array}$ & $\mathrm{BC} 3$ & GP \\
\hline $1 ?$ & 36 & $\mathrm{~F}$ & BT & 0 & 3 & BT & . & . & . & PB & MB & MB \\
\hline $2^{*}$ & 50 & $\mathbf{M}$ & BT & 1 & 9 & . & . & NO & . & PB & MB & MB \\
\hline 3 & 27 & $\mathbf{M}$ & BT & 0 & 1 & BT & 0 & NO & . & PB & $\mathrm{PB}$ & PB \\
\hline $5 ?$ & 60 & $\mathbf{M}$ & BT & 0 & 5 & . & . & NO & . & PB & MB & MB \\
\hline $6 ?$ & 36 & $\mathrm{~F}$ & BT & 0 & 3 & NO & . & NO & . & PB & MB & MB \\
\hline $8^{*}$ & 50 & $\mathrm{~F}$ & BT & 3 & 2 & BT & 0 & . & . & PB & PB & MB \\
\hline $11^{*}$ & 37 & $\mathbf{M}$ & BT & 1 & 2 & BT & 1 & . & . & PB & PB & MB \\
\hline $14 \dagger$ & 39 & $\mathrm{~F}$ & BT & 0 & 9 & BT & 2 & NO & . & MB & MB & MB \\
\hline $17 ?$ & 56 & M & BT & 0 & 9 & BT & 1 & NO & 0 & PB & MB & MB \\
\hline $20 \dagger$ & 33 & $\mathbf{M}$ & BT & 0 & 9 & BB & 3 & BB & 4 & MB & MB & MB \\
\hline $22 ?$ & 68 & M & BT & 0 & 5 & NO & . & . & . & PB & MB & MB \\
\hline $28 \dagger$ & 32 & M & BT & 0 & 9 & BT & 2 & BT & 4 & MB & MB & MB \\
\hline $30 *$ & 27 & M & BT & 2 & 3 & BT & 2 & . & . & MB & MB & MB \\
\hline $33 \dagger$ & 31 & M & BT & 0 & 6 & BT & 0 & BT & 4 & MB & MB & MB \\
\hline $34 ?$ & 55 & M & BT & 0 & 5 & TT & 0 & BT & 1 & PB & MB & MB \\
\hline 37 & 27 & $\mathrm{~F}$ & BT & 0 & 1 & NO & . & BT & 0 & PB & $\mathrm{PB}$ & PB \\
\hline $38 \dagger$ & 36 & M & BT & 0 & 9 & BT & 2 & NO & 0 & MB & MB & MB \\
\hline $39 ?$ & 41 & $\mathrm{~F}$ & BT & 0 & 4 & TT & 0 & NO & . & PB & MB & MB \\
\hline 41 & 9 & $\mathbf{M}$ & BT & 0 & 1 & $\mathrm{TT}$ & 0 & $\mathrm{NO}$ & . & PB & PB & PB \\
\hline $43 \dagger$ & 60 & $\mathbf{M}$ & BT & 0 & 8 & BT & 1 & BL & 4 & MB & MB & MB \\
\hline $44 ?$ & 55 & $\mathrm{~F}$ & BT & 0 & 3 & BT & 1 & NO & 0 & PB & MB & MB \\
\hline $46 ?$ & 36 & $\mathbf{M}$ & BT & 0 & 9 & . & . & BT & 0 & PB & MB & MB \\
\hline 49 & 51 & M & BT & 0 & 1 & BT & 0 & NO & 0 & PB & PB & PB \\
\hline $50 ?$ & 51 & M & BT & 0 & 3 & I & 0 & NO & 0 & PB & MB & MB \\
\hline 51 & 55 & M & BT & 0 & 1 & TT & 0 & NO & 0 & PB & PB & PB \\
\hline $52 ?$ & 57 & $\mathbf{M}$ & BT & 0 & 3 & BT & 0 & NO & 0 & PB & MB & MB \\
\hline $53 ?$ & 55 & $\mathrm{~F}$ & BT & 0 & 3 & BT & 1 & NO & 0 & PB & MB & MB \\
\hline
\end{tabular}

* Would have been misclassified as PB in the absence of skin smears (15\%).

$\dagger$ Would have been misclassified as PB without the body area system $(22 \%)$.

? Possibly overclassified as MB (37\%).

$\mathrm{BI}$, bacteriological index of theskin smear (highest reading); skin BI, bacteriological index of the skin biopsy; nerve BI, bacteriological index of the nerve biopsy; GP, final classification at GPH, taking into account the BC3 system + the skin-smear result.

obtaining reliable smear results in the field, led to the development of the new criteria for MB classification in Nepal.

In a recent publication ${ }^{4}$ Becx-Bleumink describes an elaborate classification system based on a score that takes into account the number and appearance of the skin lesions, as well as the number of nerves that are enlarged. In well-trained hands, this system proved remarkably reliable for correctly classifying patients into PB or MB categories.

Comparison of the system of 9 body areas, as used in Pokhara, with the 7 body area system used in Biratnager, showed no significant difference in the final $\mathrm{MB} / \mathrm{PB}$ classification between the two groups. As shown earlier in Table 7, the choice of the cutoff point for MB classification considerably affects the sensitivity and specificity of the system.

The following considerations may be important in deciding which criteria for MB classification to use: 


\section{GP histology patients}

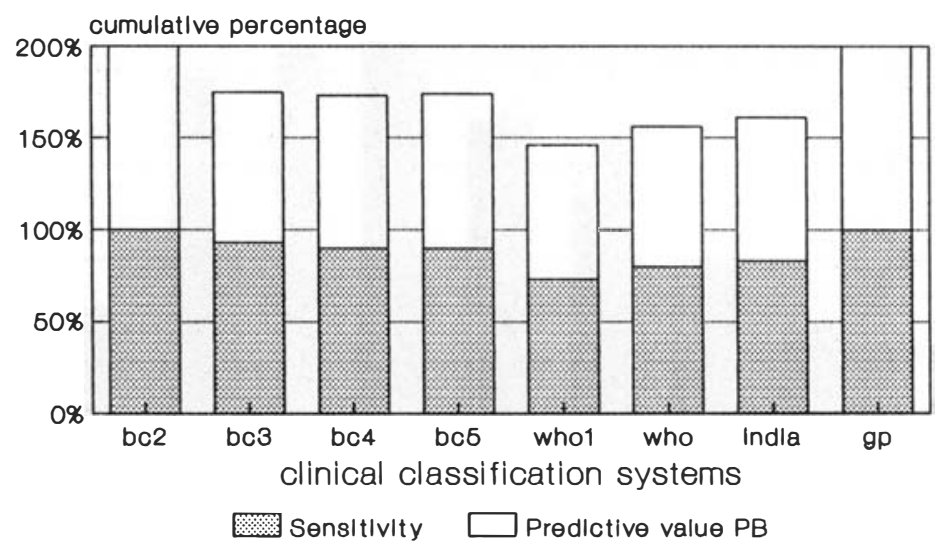

Figure 2. $n=53$. bc2, cases with 2 or more body areas involved are classified as 'M B'; bc3, cases with 3 or more body areas involved are classified as 'MB'; bc4, cases with 4 or more body areas involved are classified as 'MB'; bc5, cases with 5 or more body areas involved are classified as 'MB'; whol, WHO-recommended classification criteria, ${ }^{8}$ without skin-smear services; who, same, but with skin-smear services; india, Indian CCS: > 10 lesions $($ skin + nerve $)=\mathrm{MB}$; gp, classification system used in GPH: BC3 + skin-smear services.

1 Ability of the system to correctly identify MB cases, minimizing the number of 'false negative cases'. These are the cases classified as PB, which are, in fact, MB. This is represented by the sensitivity and the predictive value of a $\mathrm{MB}$ classification.

2 Ability of the system to minimize the number of 'false positive cases', who are classified MB but are in fact, PB. This can be an important economical consideration since false positive cases are treated unnecessarily with MB MDT. This ability is represented by the specificity of the system.

3 Ability of the system to correctly identify PB cases, i.e. the predictive capacity to say that cases diagnosed as $\mathrm{PB}$ are in fact $\mathrm{PB}$ and not $\mathrm{MB}$. This is represented by the predictive value of a PB classification.

\section{Field patients}

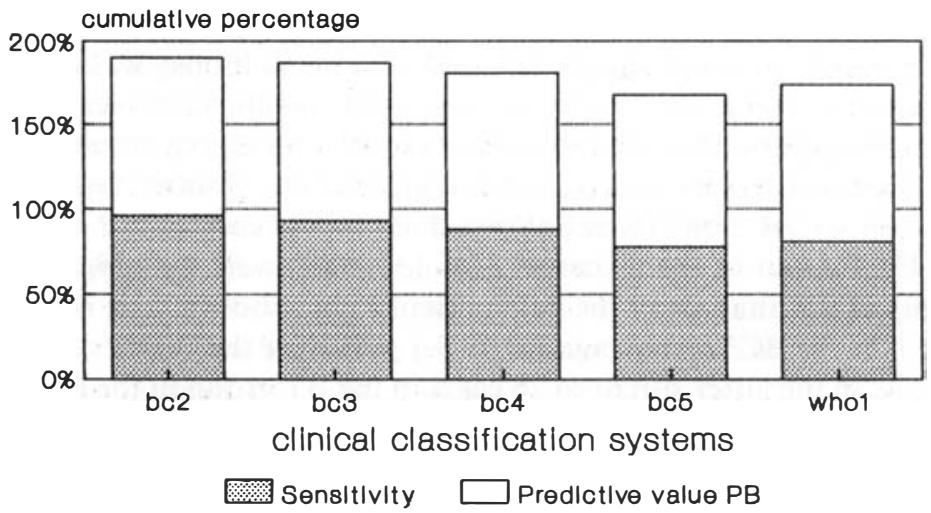

Figure 3. $n=703$. For MB criteria see Figure 2. 


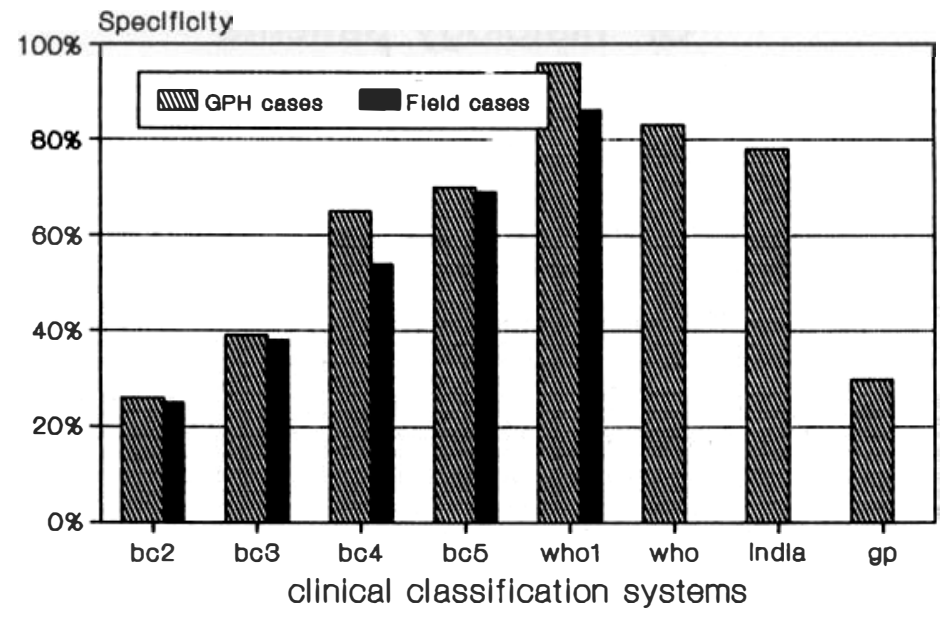

Figure 4. For MB criteria see Figure 2.

Which of the three takes priority may well vary from country to country or project to project. Since the danger of relapse is associated with 1 and 3, we feel that the sensitivity of the system and predictive value of the PB classification should have higher priority than the specificity. Although the relapse rates in trials with reliable skin-smear facilities have been very low, ${ }^{8}$ this situation may be quite different under circumstances where skinsmear services are either absent or unreliable. The computer simulation model shows that, using the current WHO classification criteria, the sensitivity drops from $80 \%$ to $73 \%$ in the absence of skin-smear results. In other words, the proportion of 'false negative cases' increases from $20 \%( \pm 14 \%)$ with skin smears, to $27 \%( \pm 16 \%)$ without skin smears, as shown in Table 7. Among the group of BT patients $(n=27)$ in GPH, $7(26 \%( \pm 17))$ are misclassified as PB using the WHO system in the absence of skin smears. This improves to $22 \%( \pm 16 \%)$ when skin smears are available. For our present body area system (BC3), these proportions are only $4 \%( \pm 5 \%)$ for all patients and $0 \%$ for BT patients respectively. The difference in false negative $\mathrm{MB}$ proportions between the simulated WHO results and the GPH results is statistically significant ( $p<0 \cdot 05$, McNemar's paired chi-square test).

Our results confirm the findings of other authors, ${ }^{16-19}$ that in a considerable proportion of patients the classification based on a nerve biopsy was MB, while the skin smear was negative or the skin biopsy showed a PB classification (see Table 10). Typical examples of a discrepancy between skin-smear result and biopsy results are given in the 4 case reports cited earlier. One might question whether our clinical classification 'MB-BT' is not in fact ' $\mathrm{BB}$ ' or 'BL', but Table 8 shows that this was only so in 2 out of 27 cases (case nos 20 and 43$)$. Six out of the 27 cases $(22 \%( \pm 16 \%))$ were histologically 'MB-BT'.

The results of the analysis of the field patient's data show a false negative proportion of $7 \%( \pm 4 \%)$ for the BC3 system against $19 \%( \pm 6 \%)$ for the WHO system without skinsmear facilities. In the latter situation 26 cases in the BT group in the field $(8 \cdot 5 \%( \pm 3 \%))$ would have been (mis)classified as PB, while in fact their skin smear was positive. Only 2 of those $(0 \cdot 7 \%( \pm 0 \cdot 9 \%))$ would have been misclassified using the $\mathrm{BC} 3$ system.

Table 9 shows that $71 \mathrm{MB}$ cases $(19 \mathrm{BB}, 36 \mathrm{BL}$ and $16 \mathrm{LL}$, which is $32 \%$ of all $\mathrm{BB}, \mathrm{BL}$ 
and LL cases), who should have been skin-smear positive, have in fact a negative BI. This may be due to inadequate smear taking techniques, laboratory mistakes (which is unlikely in such numbers, because of regular quality control), or re-registration of old, already treated patients, who were unsatisfied with their previous treatment result. There are indications that the latter may be the most likely explanation. If these cases had either been excluded from the analysis, or had been skin-smear positive, the false positive MB proportions would all have been $6 \%$ lower.

These results certainly need verification using data from a larger group of patients, preferably using data of field patients as well as referral centre patients. But there is in our opinion sufficient indication to say that, in the absence of reliable skin-smear services, that use of the present WHO criteria for MB classifcation may not be 'safe' enough. We realize, of course, that they were never intended to be used without skin smear facilities, but the difficulty of establishing good skin-smear services has nowadays been widely recognized..$^{4-7}$ It is our experience in the field programme that the weakest link lies with the smear taker, rather than with the laboratory. Despite repeated efforts to improve the quality of smear taking, the results have generally remained poor.

The weakness of the body area system compared to, for instance, the score system introduced in Ethiopia by Becx-Bleumink ${ }^{4}$ clearly lies in the high proportion of cases that are over-classified as $\mathrm{MB}$ (10.5\% in the Ethiopian score system against $61 \%$ for the BC3 system). It does seem necessary to develop the body area system further to increase its specificity. But it should be noted that the Ethiopian results are based on skin-smear results and not on histology. Nilsen et al., ${ }^{16}$ also in Ethiopia, reported that 8 out of 44 $(18 \%)$ patients with leprosy whom they studied, showed a PB histology picture in the skin, while the nerve histology revealed a BI thought to be compatible with MB leprosy. It might therefore be that the false negative proportion of the Ethiopian system is much higher in reality, than the reported $4 \cdot 9 \%$. Becx-Bleumink considers classification should be done by leprosy supervisors, we agree that this is desirable, but it is not feasible if we consider integrated leprosy control such as in Nepal, where diagnosis and classification will often have to be done by general health staff. We therefore need a system which is easy to teach and use and which in relatively inexperienced hands will produce $\mathrm{MB}$ overclassification rather than underclassification.

Counts of lesions have been used extensively in the Indian National Leprosy Eradication Programme. ${ }^{13}$ All active BT cases with more than 10 lesions receive the multibacillary regimen. In the computer model this system produces considerably fewer 'false positive cases' than the body area system $(22 \%( \pm 17 \%)$ against $61 \%( \pm 20 \%)$ respectively), but the 'false negative proportion' is much higher, particularly in the BT group $(17 \%( \pm 13 \%)$ against $7 \%( \pm 9 \%)$ for all cases; $14 \%( \pm 26 \%)$ against $0 \%$ for BT cases-see Table 7).

In Pakistan ${ }^{20}$ the $\mathrm{PB}$ regimen is only given to TT cases, with 1-5 lesions, including skin and nerve lesions and the $\mathrm{MB}$ regimen is given to all others.

A recent publication from the Medical Commission of the International Federation of Anti-Leprosy Associations (ILEP) ${ }^{21}$ states that reliable skin smears are essential for diagnosis, classification and the allocation of patients to PB or MB groups. However, a recent WHO report ${ }^{22}$ has emphasized that multidrug therapy may in fact be started before the establishment of reliable smear services, whilst at the same time advising that they should nevertheless be established as soon as possible. 
Where reliable skin-smear facilities are available a decrease in the use of 'routine sites', while including more active skin lesions in the smear taking, could considerably increase the operational value of skin smears.

In clinical classification systems the definition of nerve 'involvement' needs further study, as do variations in the number of lesions currently in use to demarcate paucifacillary and multibacillary leprosy. Considering additional clinical signs, as used in Ethiopia ${ }^{4}$ and Papua New Guinea, ${ }^{7}$ may increase the sensitivity and specificity of the system. Safeguards are needed to ensure the availability of expert opinion in cases of doubt, so that no patient is undertreated.

While we have used 3 or more body areas out of a total of 9 as main MB criterium, some may feel that the BC2 system is 'better', since it is even safer in terms of the false negative MB proportion. Increasing the cut-off point to 4 body areas (BC4) decreases the MB overclassification from $61 \%( \pm 20 \%)$ to $35 \%( \pm 19 \%)$ (Table 7$)$, but the proportion of false negative MB cases increases from 7\% ( $\pm 9 \%)$ to $10 \%( \pm 11 \%)$ (not statistically significant, due to the small number of cases). In the BT group the increase is significant $(0 \%$ to $14 \%( \pm 12 \%), p<0 \cdot 05$, McNemar's test $)$. Further increase of the cut-off point shows no advantages. Despite considerable MB overclassification, the body area system described here has worked well in practice and may prove of value in other leprosy control programmes as an aid to the more expedient implementation of multiple drug therapy, particularly if slit-skin smear services are unreliable or nonexistent.

\section{Acknowledgments}

We are grateful to Sr Maria Schimpf, Mr Iswar Khawas, Mr Prem Bhandari and the Western Region Mobile Clinic team for their valuable help in the data collection and data entry for this study. We are thankful to Dr Valerie $\mathbf{M}$ Inchley for her comments and suggestions and to His Majesty's Government of Nepal for their support in the fight against leprosy.

\section{References}

1 International Nepal Fellowship (INF). Manual for the implementation of multidrug therapy in the leprosy programme of Nepal, 1985.

2 WHO Study Group. Chemotherapy of leprosy for control programmes. Technical Report Series No. 675, Geneva, 1982.

3 Becx-Bleumink M. Operational aspects of multidrug therapy. Int J Lepr, 1989; 57: 540-51.

4 Becx-Bleumink M. Allocation of patients to paucibacillary o r multibacillary drug regimens for the treatment of leprosy - a comparison of methods based on skin smears as opposed to clinical methods - alternative clinical methods for classification of patients. Int J Lepr, 1991; 59: 292-303.

${ }^{5}$ Georgiev GD, McDougall AC. Skin smears and the bacterial index (BI) in multiple drug therapy control programs: an unsatisfactory and potentially hazardous state of affairs (Letter). Int J Lepr, 1988; 56: 101-3.

${ }^{6}$ Georgiev GD, McDougall AC. A reappraisal of clinical and bacteriological criteria in the implementation of multidrug therapy for leprosy control programmes and proposals for their better use. Lepr Rev, 1990; 64: 64-72.

7 Nash JE, Hudson BJ, Pyakalyia T. Leprosy score chart to assist classification. Letters to the Editor. Lepr Rev, 1989; 60: 242-3.

8 WHO Expert Committee on Leprosy, Sixth Report. Technical Report Series No. 768, 1988.

9 Annual Report 1989/90, International Nepal Fellowship Leprosy Control Project.

10 Ridley DS, Jopling WH. Classification of leprosy according to immunity. A five group system. Int J Lepr, 1966; 34: 255-73. 
11 Jopling WH, McDougall AC. Handbook of Leprosy, 4th Edn. Oxford: Heinemann Medical Books Ltd, 1988, p. 43.

12 Dean AG, Dean JA, Dicker RC. Epi Info, Version 5: a word processing, database, and statistics program for epidemiology on microcomputers. USD, Inc., Stone Mountain, Georgia, 1990.

13 National Leprosy Eradication Programme in India, 1989. Guidelines for Multidrug Treatment in Endemic Districts. Leprosy Division, Directorate General of Health, Ministry of Health and Family Welfare, Nirman Bhaven, New Delhi 110011.

14 Armitage P, Berry G. Statistical Methods in Medical Research, 2nd ed. Oxford: Blackwell Scientific Publications, 1987.

15 van Brakel WH, Kist P, Noble S, O'Toole L. Relapse after multidrug therapy for leprosy: a preliminary report of 22 cases in West Nepal. Lepr Rev, 1989; 60: 45-50.

16 Nilsen R, Mengistu G, Reddy BB. The role of nerve biopsies in the diagnosis and management of leprosy. Lepr Rev, 60: 28-32.

17 Nilsen R, Mshana RN, Negesse Y, Mengistu G, Kana B. Immunohistochemical studies of leprosy neuritis. Lepr Rev, 1986; 57, suppl 2: 177-87.

18 Srinivasan H, Rao KS, Iyer CGS. Discrepancy in the histopathological features of leprosy lesions in the skin and peripheral nerve. Lepr India, 1982; 54: 275-86.

19 Antia NH, Pandya NJ. Qualitative histology and quantitative bacteriology in various tissues of 50 leprosy patients. Lepr Rev, 1976; 47: 175-83.

20 Marie Adelaide Leprosy Centre, Karachi. MDR Manual for Pakistan and Azad Kashmir. 1986.

21 International Federation of Anti-Leprosy Associations (ILEP). Improving skin smears and the reading of the bacteriological index in MDT leprosy control programmes. Medical Bulletin, Issue No. 3, December 1990.

22 WHO. Report of the consultation on technical and operational aspects of leprosy. WHO/CTD/LEP/90.3. Male, Maldives, 11-15 June 1990. 


\title{
Répartition des patients lèpreux entre le groupe paucibacillaire et le groupe multibacillaire en vue d'une thérapeutique multi-médicaments, en tenant compte du nombre des parties du corps affectées par des lésions de la peau ou de la peau et des nerfs
}

\author{
W H van Brakel, R de Soldenhoff et A C McDougall
}

Résumé Au Népal, il s'est révélé difficile d'organiser et de maintenir des services fiables capables de faire des frottis de peau fendue. Un système de classification clinique pour la lèpre a donc été mis au point pour faciliter la répartition des patients entre le groupe paucibacillaire et le groupe multibacillaire en vue d'une thérapeutique multi-médicaments (TMM); 9 parties du corps sont utilisées: tête (1), bras (2), jambes (2); tronc (4). A l'aide d'un modèle de simulation informatisé et des données de 53 patients enregistrés à Green Pasture Hospital (GPH) à Pokhara et de 703 patients externes de la Région Ouest, plusieurs systèmes de classification clinique ont été évalués quant à leur sensibilité, spécificité, et valeur de prédiction pour la classification en MB ou PB, par comparaison avec la classification histologique pour les patients du GPH et la classification bactériologique pour les patients externes. La sensibilité et la spécificité du système par parties du corps utilisé actuellement ont été de 93\% et 39\% respectivement. La faible spécificité est dûe à une classification excessive en MB. La sensibilité du système de classification de l'OMS, sans service de frottis cutanés est de 73\% (la différence avec le système des parties du corps est significative: $\mathrm{p}<0,05$, test de McNemar). Nos observations histologiques confirment les publications antérieures qui indiquent que, tandis que certains cas-limites tuberculoïdes (LT) peuvent de l'extérieur avoir une 'apparence multibacillaire' et être négatif au frottis cutané, la biopsie des nerfs et parfois la biopsie de la peau peut présenter un tableau multibacillaire. Cette communication est la première à discuter du 'système parties du corps' dans l'objectif décrit, a vec les diagrammes des parties utilisées. Au Népal, ce système s'est révélé facile à utiliser et à enseigner et son emploi se justifierait dans d'autres programmes de contrôle impliquant une thérapeutique multi-médicaments, en particulier lorsque les services pratiquant les frottis de peau fendue ne sont pas fiables ou n'existent pas.

\section{La asignación de pacientes con lepra a grupos paucibacilares y multibacilares para una terapia multidroga, que toma en cuenta el número de zonas del cuerpo af ectadas por lesiones de la piel, o de la piel y nervios}

\author{
W H van Brakel, R de Soldenhoff y A C McDougall
}

Resumen En Nepal, el establecimiento y mantenimiento de servicios fiables para espécimenes por incisión de la piel han resultado difíciles. Por lo tanto, se ha desarrollado un sistema de clasificación clínica para la lepra que ayude en la asignación de pacientes a grupos paucibacilares o multibacilares para propósitos de terapia multidroga (TMD), utilizando 9 zonas del cuerpo: cabeza (1), brazos (2), piernas (2), tronco (4). Pacientes con más de dos zonas del cuerpo af ectadas se asignan al grupo multibacilar (MB) y los af ectados por solamente una o dos zonas se asignan al paucibacilar (PB). Utilizando un modelo de simulación informática y los datos de 53 pacientes registrados en la Green Pastures Hospital (GPH) en Pokhara, y 703 pacientes externos de la Región Occidental, se evaluaron dif erentes sistemas de clasificación clínica con respecto a su sensibilidad, especificidad y valor pronóstico para la clasificación $\mathrm{MB}$ o PB, comparados con la clasificación histológica de los casos GPH y la clasificación bacteriológica de los pacientes externos. La sensibilidad y especificidad del sistema de superficie de cuerpo que se usa actualmente fueron 93\% y 39\% respectivamente. La baja especificidad se debe a la sobreclasificación MB. La sensibilidad del sistema de clasificación de la OMS sin facilidades de espécimen de piel es 73\% (la diferencia con el sistema de superficie del cuerpo es significativa: $p<0,05$, prueba de McNemar). Nuestros resultados histologicos confirman publicaciones anteriores que indican que, aunque algunos pacientes Tuberculoides Incierta (BT) pueden tener una 'apariencia externa PB' y ser negativos a la prueba de espécimen de piel, su biopsia de nervios, y a veces la de piel, puede presentar un cuadro 'MB'. Esta es la primera publicación que discute un 'sistema de superficie de cuerpo' para el propósito descrito, incluyendo diagramas de las zonas empleadas. En Nepal, ha resultado fácil usar y enseñar, y se puede justificar su uso en otros programas de control que implementan TMD, especialmente si los servicios para espécimenes por incisión de la piel ha resultado no fiables o si no existen. 